\title{
Comparative economics of yields, market prices and returns of organic tomato production with that of inorganic tomato production in Kolar district of Karnataka
}

R. D. SHELKE, M. M. BHOGAONKAR AND R.V. CHAVAN

Received : 27.06.2015; Revised : 23.02.2016; Accepted : 24.03.2016

\begin{abstract}
The paper has reported the difference of yield, market prices and returns of organic tomato production with that of inorganic production in Kolar district. The study revealed that per ha average yield of tomatoes on organic farm (203.76q) was comparatively lower than that of inorganic farm (217.5q). The average per kg market price of organic tomatoes (Rs. 15.28) was found to be higher than that of inorganic tomatoes (Rs. 13.65). The output: input ratio was also higher on organic farms (3.12) compared to inorganic farms (2.76).
\end{abstract}

KEY WORDS : Yield, Marketing cost, Net returns, Output input ratio

How to cite this paper : Shelke, R.D., Bhogaonkar, M.M. and Chavan, R.V. (2016). Comparative economics of yields, market prices and returns of organic tomato production with that of inorganic tomato production in Kolar district of Karnataka. Internat. J. Com. \& Bus. Manage, 9(1): 70-72.

\section{MEMBERS OF THE RESEARCH FORUM}

Correspondence to:

R.D. SHELKE, Department of Agricultural Economics, College of Agriculture, Vasantrao Naik Marathwada Krishi Vidyapeeth, PARBHANI (M.S.) INDIA

Email: rds125@rediffmail.com

Authors' affiliations:

M.M. BHOGAONKAR, Department of Agricultural Engineering, College of Agriculture (V.N.M.K.V.), LATUR (M.S.) INDIA

R.V. CHAVAN, Department of Agricultural Economics, College of Agriculture, Vasantrao Naik Marathwada Krishi Vidyapeeth, PARBHANI (M.S.) INDIA 